\title{
Przysłowie, aforyzm, sentencja. Definicje małych form literackich w perspektywie komparatystycznej
}

Joanna Partyka

TEKSTY DRUGIE 2019, NR 2, S. 32-41

DOI: 10.18318/td.2019.2.4 | ORCID 0000-0003-0676758X

$\mathbf{N}$ a pierwszej konferencji genologicznej, przedstawiając problem gatunkowości tekstów encyklopedycznych, dość przewrotnie posłużyłam się cytatem odnoszącym się do przysłowia jako gatunku. Przywołałam wówczas słowa amerykańskiego paremiologa Archera Taylora $\mathrm{z}$ jego fundamentalnego dla badań nad przysłowiem, klasycznego już dzieła The Proverb z 1931 roku: „Definiowanie przysłowia jest zbyt trudne, by warto było je podejmować"1. Ten fakt badacz przysłów paradoksalnie udowadniał na 223 stronach, taką bowiem objętość ma książka. Taylor, do którego odwołują się wszyscy badacze

1 A. Taylor The Proverb, Harvard University Press, Cambridge 1931, s. 3: "The definition of a proverb is too difficult to repay the undertaking; and should we fortunately combine in a single definition all the essential elements and give each the proper emphasis, we should not even then have a touchstone. An incommunicable quality tells us this sentence is proverbial and that one is not. Hence no definition will enable us to identify positively a sentence as proverbial. [...] Let us be content with recognizing that a proverb is a saying current among the folk. At least so much of a definition is indisputable".
Joanna Partyka - dr

hab., pracownik

IBL PAN, kieruje Interdyscyplinarnym Centrum Retoryki Stosowanej ProRhetorica; zajmuje się historią literatury i kultury dawnej, polskiej i iberyjskiej, szczególną uwagę poświęca tekstom paraliterackim. Ostatnio opublikowała artykuł Old Polish and Spanish penitentials as a source of knowledge on folk-paganism in a Christian society, „Res Rhetorica” 2017, nr 3. Kontakt: joanna. partyka@ibl.waw.pl. 
zajmujący się małymi formami literackimi, podniósł rolę intuicji („incommunicable quality") w klasyfikowaniu jakichś zdań jako przysłów (proverb). Wydaje się zatem, że trudno skonstruować jakąś ostateczną definicję gatunku ("a definitive definition of the genre is an impossibility")2.

Wolfgang Mieder, paremiolog z amerykańskiego uniwersytetu w Vermont, żartobliwie stwierdził, że jest więcej definicji proverbiów (użył tu szerokiego znaczenia, odpowiadającego propozycji hiszpańskiej - paremii, do tego jeszcze wrócę) niż ich samych. Obliczył, że definicji tych funkcjonuje wjęzyku angielskim ponad pięćdziesiąt ${ }^{3}$. Jest to zatem termin nieostry, podobnie jak słowo kultura (ponad 150 definicji). Mieder podjął jednak próbę opisania, czym jest przysłowie, opierając się na frekwencji występujących w tych definicjach słów:

Przysłowie jest krótkim, powszechnie znanym ludowym powiedzeniem, w którym zawarta jest mądrość, prawda, moralność i tradycyjny światopogląd; ma formę metaforyczną, ustaloną i łatwą do zapamiętania i przekazywane jest z pokolenia na pokolenie. ${ }^{4}$

Czy konieczne jest zatem stwarzanie definicji gatunku w sytuacji, gdy każda kolejna próba nie kończy się satysfakcją badacza? Niewątpliwie niektóre gatunki są łatwiejsze, inne trudniejsze do zdefiniowania. Małe gatunki literackie, takie jak przysłowie czy aforyzm, należą do tej drugiej grupy. Przysłowie jest wdzięcznym materiałem dla badań literaturoznawczych i kulturoznawczych, także dla komparatystyki kulturowej. W takiej sytuacji scharakteryzowanie przedmiotu zainteresowania, ustalenie, czym jest, a czym nie jest przysłowie, jakie cechy odróżniają je od aforyzmu czy sentencji, staje się prawie koniecznością. Maciej Eder, poszukując odpowiednich narzędzi badawczych do interpretacji genologicznej Przysłów mów potocznych Andrzeja Maksymiliana Fredry, zauważa, że „Całkowita rezygnacja z ustaleń współczesnej paremiologii byłaby [...] krokiem równie ryzykownym jak

2 Tak podsumował rozważania Taylora Wolfgang Mieder (Proverbs: a Handbook, Greenwood Press, London 2004, s. 3).

3 Por. tamże, s. 3.

4 W. Mieder Proverbs Are Never Out of Season: Popular Wisdom in the Modern Age, Oxford University Press, Oxford 1993, s. 24: "A proverb is a short, generally known sentence of the folk which contains wisdom, truth, morals, and traditional views in a metaphorical, fixed and memorizable form and which is handed down from generation to generation". 
zdanie się wyłącznie na nią - dyskurs naukowy nie może się dziś obejść bez uwzględnienia dotychczasowego stanu badań"5. Dokonuje zatem przeglądu „być może nawet nie najważniejszych, ale reprezentatywnych stanowisk, z naciskiem na poglądy polskich badaczy"6. Eder, podobnie jak wielu innych „polskich badaczy”, stawia znak równości między przysłowiem, proverbium i paremią, stosując te terminy wymiennie.

Wszyscy zgadzają się co do tego, że przysłowie i gatunki mu pokrewne są ważnym elementem kultury. W potocznym myśleniu przysłowia są prawdziwsze i ważniejsze od wiedzy naukowej, ponieważ „prosty człowiek” rzadko się myli. Przez wieki przysłowie oprócz maksymy i sentencji wykorzystywano w mowach, kazaniach i tekstach publicystycznych, gdzie traktowano je jako ostateczny autorytet zbiorowej mądrości. W przysłowiach świat wydawał się - i wydaje nadal - czytelny i przewidywalny, podają one bowiem prostą wiedzę, którą dzięki odpowiedniej formie można bez większego wysiłku przyswoić. Arystoteles widział w przysłowiach „podstawową filozofię”, wielokrotnie przywołuje je w Retoryce. Max Scheler uważał, że przysłowia stanowią klucz do elementarnej wizji świata7. Dziś stosuje się je niemal wyłącznie w funkcji zabawowej, ale utrwalone w nich spostrzeżenia są cenne nie tylko dla językoznawcy czy literaturoznawcy, ale także dla antropologa badającego przejawy świadomości kulturowej ${ }^{8}$.

Zainteresowanie przysłowiem powraca dość regularnie co parędziesiąt lat. Intensywnie przyglądano mu się w latach 30., następnie 70. Ostatnie dwadzieścia lat to ponowna fascynacja tym gatunkiem (czy gatunkami). Światową „stolicą” przysłów jest od jedenastu lat portugalska Tavira. Odbywają się tam coroczne kolokwia poświęcone przysłowiu - spotkania paremiologów, paremiografów i entuzjastów tej formy paraliterackiej z całej Europy, także folklorystów, historyków, literaturoznawców i tłumaczy, należących do Associação Internacional de Paremiologia/International Association of Paremiology (AIP-IAP). Od 1964 roku ukazuje się rocznik „Proverbium. Yearbook of International Proverb Scholarship”. Wydawany początkowo

5 M. Eder U źródeł aforystyki polskiej. Studium o "Przysłowiach..." Andrzeja Maksymiliana Fredry, Oficyna Wydawnicza ATUT, Wrocław 2008, s. 54.

6 Tamże.

7 Por. K. Kuszak Przysłowie jako językowy nośnik wartości - perspektywa pedagogiczna, "Studia Edukacyjne" 2013 nr 26, s. 39-62.

8 Por. T. Hołówka Myślenie potoczne. Heterogeniczność zdrowego rozsq̨dku, przedm. M. Czerwiński, PIW, Warszawa 1986, s. 125-143 (rozdz. Co kryje się w przysłowiach? i Eklektyzm) 
w Finlandii, obecnie od wielu lat publikowany jest w Stanach Zjednoczonych; od 1984 roku pieczę nad nim sprawuje wspomniany już Wolfgang Mieder. Jest to najważniejsze na świecie forum paremiologów. Od 1993 roku regularnie wydawany jest hiszpański rocznik „Paremia”.Już same tytuły czasopism mogą sugerować problem terminologiczny. Oba terminy - paremia i proverbium używane są także przez polskich badaczy. Mieder stosuje wymiennie oba - paremia i proverb.

Od początków pojawienia się myśli paremiologicznej, czyli od XVI wieku (Maciej Eder przekonuje, że refleksja paremiologiczna obecna była już w starożytnej Grecji i Rzymie9), istnieją kłopoty definicyjne - jasno wykładane już przez pierwszych paremiologów. Na przykład hiszpański językoznawca Sebastian Covarrubias w Tesoro de la lengua castellana o española (1611) nie widzi różnicy między przysłowiem (refrán), a adagium i proverbium: „Przysłowie jest tym samym, czym adagium. Proverbium także, ponieważ odnoszą się do siebie nawzajem"10.

Stownik terminów literackich podaje taką definicję przysłowia:

Zdanie występujące w obrębie danej kultury w stałej postaci, wyrażające w formie bezpośredniej lub zmetaforyzowanej pewną myśl czy naukę ogólną, odnoszącą się do określonej sytuacji życiowej; ma postać stwierdzenia lub pouczenia, zwykle zbudowanego na zasadzie paralelizmu lub kontrastu znaczeniowego [...], nierzadko rymowanego wewnętrznie. Przysłowia powstają i funkcjonują przede wszystkim w kulturach zamkniętych i tradycyjnych, są przeto istotnym składnikiem ludowej literatury. ${ }^{11}$

Paremiolodzy polscy i obcy są zgodni co do tego, że nie istnieją wyraźne granice między przysłowiem a maksymą, sentencją i aforyzmem. Polscy badacze problem ten sygnalizowali już dawno. Nie było też długo zgody co

9 M. Eder Uźródeł aforystyki polskiej, rozdz. Antyczne i nowożytne definicje przysłowia, s. 59-72.

10 S. Covarriubias Orozco Tesoro de la lengua castellana o española compuesto por el licenciado Don Sebastian de Covarrubias Orozco, Capellan de su Magestad, [...] Consultor del Santo Oficio de la Inquisición, por. Luis Sanchez, impressor del Rey NS, Madrid 1611, s. 1253: „Refrán es lo mismo que adagio. Proverbio es referido porque se refiere de unos en otros". Termin refrán pochodzi od czasownika referir'odnosić się' (referido - 'odnoszący się').

Słownik terminów literackich, red. J. Sławiński, wyd. 2, Ossolineum, Wrocław 1988, s. 412, hasło opracował Michał Głowiński. 
do tego, czy traktować te drobne teksty jako odrębny gatunek literacki. Stanisław Bystroń zanegował potrzebę tworzenia teorii przysłowia ${ }^{\mathbf{1 2}}$, natomiast Julian Krzyżanowski uznał przysłowie za utwór literacki, który ma swoje cechy wyróżniające, sobie właściwą estetykę i artyzm ${ }^{13}$. Skonstatowano, że przysłowie cechuje: alegoryczność, obrazowość, dydaktyzm, często komizm. Dydaktyzm i powszechność przysłowia łączą je z maksymą i sentencją, którym z kolei najczęściej brakuje obrazowości. Maksymę i sentencję traktuje się często jako synonimy i definiuje jako "ogólne abstrakcyjne prawdy i nauki” czy „formułki zalecające zasady postępowania moralnego”. Są mniej zwięzłe od przysłowia, a konkretności tego ostatniego przeciwstawiają ogólność. Ponadto maksyma jest bardziej poważna w treści. Trafne i użyteczne wydaje się sformułowanie, że przysłowie to sfolkloryzowany aforyzm. Różnica między przysłowiem a aforyzmem polegałaby zatem m.in. na stopniu popularności. Gdy aforyzm staje się popularny, traci autora i wchodzi do powszechnego obiegu jako przysłowie.

W angielskiej Wikipedii hasło proverb jest niezwykle dokładnie, rzeczowo i kompetentnie potraktowane, opatrzone bogatymi odnośnikami bibliograficznymi, obejmującymi całokształt wiedzy w wielkim skrócie. Potraktowano to hasło bardzo poważnie, co jest znamienne. W polskiej Wikipedii pod hasłem przysłowie nie ma prawie nic (dostęp: 18.04.2018); w odnośniku Zobacz też jedynym wskazanym linkiem są przysłowia niderlandzkie... W bibliografii - jedyny autor to Grzegorz Szpila, prawdopodobnie autor hasła...

Szpila sformułował długą definicję przysłowia (paremii), asekurując się wcześniej - i idąc w tym za Archerem Taylorem - że jest to zjawisko trudne do zdefiniowania:

Przysłowie to krótkie, proste, często rymowane powiedzenie w postaci zdania, zwykle metaforyczne, zawierające jakąś prawdę lub mądrość opartą na doświadczeniach ludzi; służące opisaniu jakiejś sytuacji i pouczeniu; o ludowej proweniencji; charakterystyczne dla danej społeczności i powszechnie w niej znane; od wieków zakorzenione w tradycji i przekazywane z pokolenia na pokolenie. ${ }^{14}$

J.St. Bystroń Przysłowia polskie, PAU, Kraków 1933, s. 2. Przysłowie według Bystronia to „zespół wyrazów o najrozmaitszej formie i treści, powtarzanych tradycyjnie". Por. J. Krzyżanowski Szkice folklorystyczne, t. 3: Zzagadnień przysłowioznawstwa, Wydawnictwo Literackie, Kraków 1980 (passim). 
Szpila nazywa przysłowie minitekstem, postrzega je jako zamkniętą całość, posiadającą cechę zdaniowości. To ostatnie stwierdzenie wydaje się kontrowersyjne, ponieważ nie każda miniforma, którą intuicyjnie uważamy za przysłowie, jest zdaniem czy równoważnikiem zdania. Autor posługuje się terminem paremia, traktując je jako synonim przysłowia. „Z uwagi na to, że niniejsza pozycja nie jest książką o polskich przysłowiach, lecz o przysłowiu w ogóle, przykłady paremii pochodzą z różnych języków indoeuropejskich używanych w Europie"15.

Z kolei hiszpańscy badacze zajmujący się małymi formami literackimi paremię traktują szerzej niż przysłowie. W czasopiśmie „Paremia” w roku 2013, a więc stosunkowo niedawno, ukazał się niezwykle ważny artykuł podejmujący kwestię klasyfikacji gatunków, które nas tu interesują. Wydaje się, że jak do tej pory jest to najsensowniejsza propozycja. Tekst w doskonały sposób porządkuje kwestie terminologiczne, które od lat (wieków) stanowią przedmiot, jeśli nie dyskusji, to namysłu. Tytuł brzmi Las paremias y su clasificación [Paremie i ich klasyfikacja]. Tekst napisało dwoje liczących się hiszpańskich paremiologów - Julia Sevilla Muñoz i Carlos Alberto Crida Álvarez. Paremia to: ,jednostka frazeologiczna zbudowana z krótkiego i sentencjonalnego wypowiedzenia, odpowiadającego prostemu lub złożonemu zdaniu, która została ustalona w mowie i stanowi część dziedzictwa społeczno-kulturowego zbiorowości mówiącej"16. Paremie podzielili na: paremie znanego pochodzenia i o „wysokim" użyciu (proverbium, aforyzm) oraz paremie anonimowe o „niskim”, ludowym użyciu (przysłowia, zdania przysłowiowe, wyrażenia czy zwroty przysłowiowe i welleryzmy), przy czym zaznaczają, że podział ten dotyczy paremii występujących w języku hiszpańskim i w innych językach romańskich, a także w języku nowogreckim. Czy dałoby się podzielić w ten sposób polskie paremie? Oczywiście!

Proverbium (nie to samo, co angielskie proverb u Taylora) wiążą hiszpańscy autorzy z tradycją biblijną i antyczną. Są to zatem paremie wywodzące się z kultury antycznej czy wczesnochrześcijańskiej, choć włączyli tu też powiedzenia związane z innymi dawnymi kulturami - paremie chińskie czy arabskie. Z kolei aforyzm ma swojego autora: filozofa, znanego polityka, pisarza,

15 G. Szpila Krótko o przysłowiu, s. 11.

"[...] una unidad fraseológica constituida por un enunciado breve y sentencioso, que corresponde a una oración simple o compuesta, que se ha fijado en el habla y que forma parte del acervo socio-cultural de una comunidad hablante", J. Sevilla Muñoz, C.A. Crida Álvarez Las paremias y su clasificación, "Paremia” 2013 no. 22, s. 106 (cały art.: s. 105-114). 
choć może to być także postać fikcyjna. Zdaniem badaczy synonimiczne terminy to: maksyma, apoftegmat, sentencja, choć wskazują oni na pewne różnice między nimi, np. to, że maksyma przekazuje jakąś normę moralną czy też refleksję filozoficzną (por. Maksymy La Rochefoucauld). Wyróżniono tu aforyzmy etyczne, polityczne oraz te o pochodzeniu naukowym czy profesjonalnym, wyjaśniającym pewne zasady, prawa czy aksjomaty, jak np. „Wyjątek potwierdza regułę" (z prawa średniowiecznego). Hiszpański termin refrán odpowiada polskiemu przysłowiu. Hiszpanie podają taką definicję tej odmiany gatunku paremicznego: „paremia o nieznanym pochodzeniu, powszechnie używana, o strukturze najczęściej dwuczłonowej, zawierająca często elementy mnemotechniczne; często żartobliwa, oparta na doświadczeniu i, najczęściej, mająca wartość prawdy uniwersalnej"17. Przysłowia podzielone zostały na: przysłowia o zasięgu ogólnym, o zasięgu ograniczonym (w czasie, przestrzeni, zawężone do jednej grupy społecznej czy kulturowej), zdania przysłowiowe (cechujące się jednoczłonowością, bez elementów mnemotechnicznych, np. „Ściany mają uszy”), wyrażenia czy zwroty przysłowiowe oraz dialogizm (wśród dialogizmów wyróżniony został welleryzm jako jedna z jego form; Szpila natomiast wyróżnia przysłowia dialogowe i welleryzmy jako dwie osobne grupy). Hiszpańscy paremiolodzy zastrzegają, że niektóre paremie trudno zaklasyfikować, że granice bywają nieostre. I kończą artykuł przysłowiem: „Wyjątek potwierdza regułę”. To, co dziwi nieco w przywołanym tu tekście, to "odkrycie", że hiszpańskie paremie mają swoje odpowiedniki w innych językach romańskich, najczęściej we francuskim, a także nowogreckim, natomiast z powodzeniem daje się je porównywać z repertuarem paremiograficznym z innych grup językowych ze skutkiem niezwykle interesującym i pouczającym. I tu ważna moja obserwacja: Najwięcej „wspólnych” paremii, „ekwiwalentów paremicznych” (Szpila) znaleźć można w grupie nazwanej przez Álvareza i Muñoz proverbiami. Przykładów dostarczają Bajki Ezopa. Łacińska paremia Oculus domini saginat equum, która ma swoje źródło w Bajkach, popularna jest w przekładzie dosłownym w języku polskim („Pańskie oko konia tuczy”), angielskim („The master's eye maketh the horse fat”), portugalskim („O olho do amo engorda o cavalo”) i hiszpańskim („El ojo del amo engorda al caballo").

Wszystkie opracowania - artykuły i książki - poświęcone małym gatunkom literackim rozpoczynają się ustaleniami genologicznymi, próbą określenia różnic między przysłowiem, sentencją i aforyzmem. Jedną z ostatnich

Tamże, s. 111. 
polskich monografii jest praca zbiorowa Aforyzm europejski. Studia i szkice ${ }^{\mathbf{1 8}}$. Mieczysław Balowski w pierwszym artykule, zatytułowanym Aforyzm w perspektywie genologicznej i dyskursywnej, pisze:

We współczesnych opracowaniach teoretycznoliterackich aforyzm umieszczany jest wśród takich gatunków, jak: apoftegmat, gnoma, maksyma, sentencja, złota myśl czy przysłowie. Niekiedy do tej grupy włącza się jeszcze skrzydlate słowa. Nie są to jednak gatunki tożsame, choć często utożsamiane. ${ }^{19}$

Autor, lingwista, zaczyna ab ovo, czyli od określenia, czym jest gatunek literacki/paraliteracki. Jest to zatem „historycznie/kulturowo ukształtowany sposób językowego komunikowania się”. Jest „kilka sposobów jego realizacji”:

Prymarnie gatunek to:

1) właściwość konkretnego tekstu,

2) właściwość konkretnego tekstemu jako jednostki poziomu tekstowego w systemie,

3) składniowa właściwość kompetencji językowo-komunikacyjnej nadawcy i odbiorcy.

Sekundarnie zaś gatunek to:

4) (potoczne i ) naukowe ujęcie modelu tekstu, systemu i kompetencji gatunkowej,

5) sztuczna norma o preskryptywnym charakterze, której kodyfikatory bazują (najczęściej) na potocznej wiedzy genologicznej [wyróż. - J.P.]. ${ }^{20}$

Rozważania Balowskiego są interesujące $\mathrm{z}$ wielu powodów. Bardzo istotne jest np. to, że uchwycił on moment przejścia aforyzmu w przysłowie, choć nie pisze o tym zjawisku. W świetle tych ustaleń aforyzm jawi się bowiem jako

18 Aforyzm europejski. Studia i szkice, red. A. Jarzyna, J. Jęcz, M. Junkiert, K. Kuczyńska-Koschany, Pasaże, Kraków 2015.

M. Balowski Aforyzm w perspektywie genologicznej i dyskursywnej, w: Aforyzm europejski, s. 11.

20 Tamże, s. 12. 
gatunek o niestabilnej formie, [...] rozwijający się bardzo dynamicznie, o czym świadczy jego duża wariantywność zwłaszcza w wieku XVII, wynikająca z negocjacji między pierwotnym i wtórnym nadawcą (autorem i odtwórcą aforyzmu) a odbiorcą (słuchaczem, interlokutorem), polegającej przede wszystkim na nowej konceptualizacji aforyzmu w sytuacji komunikacyjnej, w której się oni znajdują. ${ }^{21}$

Podejmując rozważania terminologiczne na temat małych gatunków literackich w kontekście literatury dawnej, nie sposób nie wspomnieć o Przysłowiach mów potocznych Andrzeja Maksymiliana Fredry. Ostatnią monografią poświęconą twórczości kasztelana lwowskiego jest wspomniana już praca Macieja Edera U źródeł aforystyki polskiej. Studium o „Przysłowiach...” Andrzeja Maksymiliana Fredry. W tytule zawarta jest teza: Przysłowia Fredry to nie przysłowia, lecz aforyzmy. „[...] dziełko [Fredry] niewiele ma wspólnego z typowymi zbiorami przysłów”, zauważa autor ${ }^{22}$. "Typowy” zbiorek przysłów to Przypowieści polskie Salomona Rysińskiego (1618). Przysłowia Fredry są (w dużej części) aforyzmami, Przypowieści Rysińskiego to przysłowia. Zamieszanie trwa...

Nie ulega wątpliwości, że termin „przysłowie” - odpowiednik (?) łacińskiego proverbium - nie był ani określeniem jedynym, ani nawet najważniejszym, nietrudno też zauważyć, że pisarze najczęściej sięgają po słowo „przypowieść”. Wciąż jednak otwarte pozostają pytania, jakie jest dokładnie znaczenie tych wyrazów, czym różnią się od siebie nawzajem i w jakim stopniu odpowiadają terminologii łacińskiej”."3

Eder udowodnił w swojej niezwykle cennej monografii, że Przysłowia Fredry to początek polskiej aforystyki. A czym jest aforyzm? To pojęcie w czasach starożytnych kojarzono wyłącznie ze zbiorem porad lekarskich przypisywanych Hipokratesowi. Był to poradnik, a nie dzieło literackie. Nowożytny aforyzm XVII-wieczny to już zupełnie inny gatunek...

21 Tamże, s. 15-16.

22 M. Eder Uźródełaforystyki polskiej, s. 53.

23 Tamże, s. 87. 


\section{Abstract}

\section{Joanna Partyka}

THE INSTITUTE OF LITERARY RESEARCH OF THE POLISH ACADEMY OF SCIENCES (WARSAW)

Proverb,Aphorism, Maxim:Defining Minor Literary Forms from a Comparative Perspective

Scholars of minor literary forms such as the proverb, maxim or aphorism face the problem definition. To define a genre becomes a necessity especially when it comes to comparing similar forms from different cultural contexts. The difficulty, then, is not only to juxtapose a form's characteristics and to describe it in a way that would allow us to tell it apart from related forms, but also to label the form. What is called "przysłowie" (proverb) in Polish is known by a variety of terms in different languages; most often these terms derive from the Latin (proverbium) or Greek (paremia). Another complication is related to the fact that scholars of minor literary forms in Spain, for instance, treat paremia as a category that is broader than the proverb. The lack of parallelism and consistency accounts for the abiding confusion about the genre of the proverb.

\section{Keywords}

literary genre, proverb, aphorism, paremia, paremiology, comparative literature 